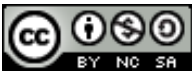

https://doi.org/10.31743/abmk.12433

MARCIN JANAKOWSKI* - LUBLIN

\title{
„COMPENDIUM ARCHIVI KIELCENSIS” - KILKA UWAG NAD „KIELECKIM” ARCHIWUM I KANCELARIĄ ZADWORNĄ BISKUPA KRAKOWSKIEGO KAJETANA SOLTYKA
}

\section{Streszczenie}

Dzieje i funkcjonowanie archiwów oraz kancelarii biskupów krakowskich pozostają wciąż otwartymi tematami badawczymi. Systematycznie udaje się jednak uzupełniać ten obraz o mniej lub bardziej szczegółowe rozważania nad konkretnymi obszarami działalności instytucji kościelnych, zwłaszcza na poziomie regionalnym. Do takiego typu badań należy zaliczyć studia nad funkcjonowaniem kieleckiego archiwum biskupa Kajetana Ignacego Sołtyka. Przechowywany w Bibliotece XX Czartoryskich XVIII-wieczny kodeks Compendium Archivi Kielcensis jest jednym z ważniejszych źródeł prezentujących praktykę kancelaryjną oraz wymiar decentralizacji administracji biskupiej. Szczegółowa analiza tego materiału pozwala również ukazać rolę Kielc jako jednej z głównych siedzib ordynariuszy krakowskich, a także rolę tego ośrodka w systemie administracji kościoła krakowskiego.

Najbardziej interesującym elementem przywołanego kodeksu, z perspektywy moich rozważań, jest inwentarz kieleckiego archiwum biskupa Sołtyka, którego zwartość została poddana analizie w niniejszym artykule. Kolejnymi elementami badań była także próba wskazania okoliczności, w jakich został wyodrębniony ten element kancelarii biskupiej oraz określenie związków przechowywanej tam dokumentacji z Kielcami. Istotną częścią studiów nad omawianym archiwum jest przedstawienie jego dziejów, a następnie wpisanie ich w historię funkcjonującego do dziś Archiwum Diecezjalnego w Kielcach.

Słowa kluczowe: Kajetan Ignacy Sołtyk; archiwum; kancelaria; Kielce;

Biblioteka XX Czartoryskich; diecezja krakowska

\footnotetext{
* Marcin Janakowski - mgr historii, doktorant w Instytucie Historii, Uniwersytet Marii Curie -Skłodowskiej w Lublinie

e-mail: marcin.janakowski@wp.pl

https://orcid.org/0000-0002-1578-3859
} 
Kancelaria, a raczej kancelarie biskupów krakowskich nie cieszą się dziś zainteresowaniem adekwatnym do zachowanego zasobu źródłowego i jego znaczenia dla badań nad przeszłością naszego kraju. Podobna sytuacja odnosi się także do rozważań nad funkcjonowaniem biskupich lub kapitulnych archiwów, tudzież stosowanych tam systemów kancelaryjnych. Szczególnie dotkliwe wydają się braki takich studiów dla końca XVII i XVIII wieku, kiedy masowość wytwarzanej dokumentacji oraz systematyczne adaptowanie się do rzeczywistości biurokratycznej istotnie wpłynęły na procesy zarządzania, a zatem również aktotwórstwa i archiwizacji. Pozostające do dyspozycji historyków nieliczne prace, obejmujące chronologicznie głównie wieki średnie, nie zbliżają zatem do pełnego rozpoznania tej niezwykle istotnej części administracji Polski przedrozbiorowej ${ }^{1}$. Zważywszy na wielkość terytorium, znajdującego się we władaniu biskupów krakowskich, nie można pomijać systemu zarządzania i kierowania tak znaczną częścią obszaru Rzeczypospolitej.

O tym, że badania nad dziejami kancelarii oraz archiwów, zarówno jako instytucji związanych z aktotwórstwem, administracją, jak i ich środowiskiem urzędniczym stanowią istotny element poznania przeszłości, świadczą liczne prace poświęcone kancelariom oraz archiwom monarszym, miejskim czy prywatnym² ${ }^{2}$. Wydaje się, że niedostatecznie reprezentowane są w obecnej historiografii studia nad kancelariami i archiwami kościelnymi, a szczególnie biskupimi, które ze względu na swoją specyfikę, łącząc instytucje o charakterze na poły prywatnym oraz publicznym, są trudnym polem badawczym. Istotne wydają się choćby prace przyczynkowe, naświetlające wybrane problemy i określające postulaty badawcze. Celem niniejszych rozważań jest zatem przeprowadzenie wstępnego rozpoznania i analizy jednego ze źródeł, obrazujących funkcjonowanie archiwum i kan-

${ }^{1}$ Niewątpliwie za fundamentalne prace w tej dziedzinie należy uznać dzieło A. Tomczaka, Kancelaria biskupów włocławskich w okresie księgi wpisów (XV-XVIII w.), Toruń 1964 oraz odnoszące się chronologicznie do wieków średnich studia R. Żerelika, Kancelaria biskupów wrocławskich do 1301 roku, Wrocław 1991. Chlubnymi wyjątkami, choć również pióra mediewistów, są prace autorstwa E. Knapek, Księga wpisów biskupa krakowskiego Jana Lutka z Brzezia z lat 14641471, w: Ecclesia regnum fontes. Studia z dziejów średniowiecza, red. R. Michałowski, Warszawa 2014, s. 416-425; T. Jurka, Pozostałości regestru kancelarii biskupa wrocławskiego Jana Romki (1292-1301) na skrawkach makulatury przypadkiem zachowane, w: Ecclesia refnum fontes, s. 346359; A.M. Włoch, Kancelaria i dokumenty biskupa krakowskiego Piotra Wysza (1392-1412), „Studia Źródłoznawcze”, 46 (2009) s. 29-82 czy K. Bobowskiego, Kancelaria oraz dokumenty biskupów $i$ kapituły w Kamieniu (do końca XIII w.), Wrocław 1990. Pewnym szczęśliwym wyjątkiem wydaje się zatem praca B. Turonia, $Z$ dziejów kancelarii biskupów wroctawskich w Nysie w latach 16011700, „Sobótka”, 19 (1964) s. 88-96.

${ }^{2}$ Pozwalam sobie na przywołanie jedynie kilku fundamentalnych prac, jak K. Syta, Archiwa magnackie w XVIII wieku. Studium kultury kancelaryjno-archiwalnej, Toruń 2010; K. Buczek, Z dziejów polskiej archiwistyki prywatnej. Archiwa XX. Czartoryskich, Kraków 1938; W. Chorążyczewski, Przemiany organizacyjne polskiej kancelarii królewskiej u progu czasów nowożytnych, Toruń 2007; J. Łossowski, Kancelarie miast szlacheckich województwa lubelskiego od XV do XVIIIwieku, Lublin 1997; tenże, Kancelaria grodzka chetmska od XV do XVIII wieku. Studium o urzędzie, dokumentacji, jej formach i roli w życiu społeczeństwa staropolskiego, Lublin 2004, tam też czytelnik odnajdzie szeroką literaturę przedmiotu. 
celarii biskupiej poza stołecznym dworem w Krakowie, mianowicie sumariusza kieleckiego archiwum biskupa krakowskiego Kajetana Sołtyka.

Wskazówki co do jego istnienia przyniosła kwerenda w Bibliotece Książąt Czartoryskich w Krakowie, gdzie pod sygnaturą nr 1060 IV znajduje się XVIIIwieczny, liczący 737stron (399 kart), papierowy, oprawny w skórę kodeks, określany w katalogu Biblioteki jako „Inv. Summaryusz dokumentow w arch. kieleckiem znajdujących się. Compendium archivi Kielcensis. Episcopalia et diecesana in archivo Kielcensi JOXcia JMci Sołtyka bisk. krak. Z XVIII wieku" [!] ${ }^{3}$. Stanisław Kutrzeba, sporządzając powyższy katalog, wykorzystał incipit kodeksu do skonstruowania jego tytułu. Wydaje się to zasadne, gdyż próżno szukać w nim karty tytułowej, wskazującej poza nazwą na czas, autora i okoliczności powstania. Wątpliwości rozwiewa wyciśnięty w skórze, na przedniej części oprawy, napis: „Compendium Archivi Kielcensis”, co wydaje się właściwym tytułem całego kodeksu.

Kompendium składa się z trzech zasadniczych części, tj. opisu zawartości kieleckiego archiwum biskupa Kajetana Sołtyka ${ }^{4}$, sumariusza najważniejszych bulli papieskich oraz przywilejów wystawianych dla kościołów i duchowieństwa diecezji krakowskiej ${ }^{5}$, a następnie obszernych regestów dokumentów odnoszących się do poszczególnych kluczy dóbr biskupstwa krakowskiego ${ }^{6}$. Zostało ono sporządzone przez co najmniej trzech pisarzy, na co wskazuje niejednorodny charakter pisma. Poszczególne części były systematycznie uzupełniane, o czym świadczą liczne dopiski i glosa na marginesach, wyróżniające się duktem pisma oraz użytym atramentem. Niełatwym zadaniem jest natomiast ustalenie daty wykonania zarówno całego kompendium, jak i widniejącego na pierwszych kartach opisu zasobu „kieleckiego archiwum”. Istotne w tym ujęciu wydają się przywoływane dokumenty ekonomiczne, stanowiące niemal raporty o dochodach płynących z poszczególnych kluczy gospodarczych. Sprawiają one wrażenie bardzo szczegółowych oraz aktualnych, stanowiąc przy tym grupę chronologicznie najpóźniejszych wpisów, opatrzonych obok dat rocznych miesięcznymi, a czasem dziennymi. Dzięki temu można stwierdzić, iż kodeks zakończono spisywać nie wcześniej niż 9 kwietnia 1760 r., gdyż właśnie pod tą datą widnieje ostatni wpis?

Jak można przypuszczać, powodem sporządzenia tegoż kompendium była chęć przygotowania podręcznej pomocy kancelaryjnej, informującej o zasobie archiwum kapituły krakowskiej, w czasie przebywania ordynariusza poza stolica diecezji, a zatem pozbawionego możliwość korzystania z tamtejszej kancelarii lub archiwum. Wiele wskazuje, iż stosowano go również jako swoisty kopiariusz, na podstawie którego można było dokonywać odpisów lub weryfikacji dokumen-

${ }^{3}$ Biblioteka XX Czartoryskich w Krakowie (dalej: B. Czart), sygn. 1060 IV; Catalogus codicum manu scriptorum Musei Principum Czartoryski Cracoviensis. Vol. II, ed. S. Kutrzeba, Cracoviae 1908-1913.,s. 88-89.

${ }^{4}$ B. Czart. sygn. 1060 IV, k. 6-7v.

${ }^{5}$ Tamże, k. 8-38v.

${ }^{6}$ Tamże, k. 39-396.

${ }^{7}$ Tamże, k. 392v. 
tów ${ }^{8}$. Już samo określenie „kompendium” jednoznacznie wskazuje na charakter dzieła. Prawdopodobnie wykorzystywano je w tzw. kancelarii zadwornej, której podstawową funkcją było umożliwienie działania administracji w czasie podróży lub wizytacji biskupiej. Zakres działalności owej kancelarii był właściwie analogiczny do tej, która funkcjonowała w stołecznym Krakowie. Jej prace dotyczyły spraw sądowych, małżeńskich, kryminalnych, duszpasterskich, a także ekonomicznych, co w odniesieniu do treści kieleckiego kompendium wydaje się szczególnie istotne. W czasach pontyfikatu bpa Kajetana Sołtyka funkcje kierownicze sprawowali tam Stanisław Minocki oraz Jan Nepomucen Modzelewski. Ustalenie autorstwa któregoś z nich wydaje się możliwe dopiero po przeprowadzeniu testów grafologicznych, co również może stanowić interesujący, interdyscyplinarny kierunek badań nad kancelarią biskupa Sołtyka9 .

Pewne praktyczne cechy kompendium potwierdza fakt, iż nie był to jedyny lub wyjątkowy tego typu sumariusz. Kodeks o podobnym charakterze znajduje się pod sygnaturą 1059 IV w zasobie Biblioteki Książąt Czartoryskich. Jest to Sumariusz Przywilejów i różnych Papierów w Archiwum Kościoła Katedralnego Krakowskiego spisany w 1757 roku przez Krzysztofa Hilarego Szembeka ${ }^{10}$. Tytuł sumariusza jest zbieżny z jego zawartością. Interesujące jest natomiast, że fragmenty dotyczące bulli papieskich oraz przywilejów dla kościoła krakowskiego, zawarte w obu sumariuszach z Biblioteki Czartoryskich, są niemal identyczne ${ }^{11}$. Pozwala to sądzić, iż kompendium kieleckie było sporządzone na podstawie innego spisu lub sumariusza, prawdopodobnie krakowskiej proweniencji. Takie pochodzenie zdają się również potwierdzać liczne podobieństwa, zarówno w odniesieniu do opraw kodeksów, jak i stylistyki pisarskiej, do niektórych akt wizytacji biskupich znajdujących się w Archiwum Kurii Metropolitalnej w Krakowie ${ }^{12}$.

Ewentualna próba odszukania pozostałych odpisów i zestawienie ich z najstarszymi inwentarzami oraz spisami zasobu archiwów katedralnego i metropolitalnego w Krakowie mogłaby przynieść ciekawe informacje odnośnie do szerszego funkcjonowania biskupich kancelarii zadwornych. Dotychczasowa, wstępna kwerenda w Archiwum Kurii Metropolitalnej nie przyniosła jednak przełomowych ustaleń. Ze względu na swoją objętość i różnorodność treści kompendium zawiera w sobie obraz ekonomiczny i prawny niemal całej diecezji krakowskiej, co już samo stanowi wciąż interesujący przedmiot dociekań badawczych. W od-

\footnotetext{
${ }^{8}$ Jeden z „rozdziałów” poprzedza następujący zapis: „Summaryusz y zebranie xięgi w białą Pargaminową Kompaturę Oprawney. Granice, Działy, Kompozycye Przyiacielskie całego Włodarstwa Biskupstwa Krakowskiego w Sobie Zawieraiącey Ex Archivo Capituli Cracoviensis za S.P. JO Xcia Imci Kardnała Biskupa Krakowskiego Pieczęcią Reverendissimi Capituli Cracoviensis stwierdzoney excerptowaney 1740. Więc w Granicznych Interesach całego Biskupstwa według tego Summaryusza referować się potrzeba do teyże Xięgi”, tamże, k. 39.

${ }^{9}$ B.S. Kumor, Dzieje diecezji krakowskiej do roku 1795, t. 2, Kraków 1999, s. 28-38.

${ }^{10}$ Krzysztof Hilary Szembek (1722-1797), późniejszy biskup płocki, zob. B. Czart, sygn. 1059 IV.

${ }^{11}$ Por. B. Czart., sygn. 1059 IV, k. 3-10 B. Czart., sygn. 1060 IV, k. 15-21.

${ }^{12}$ Tamże, sygn. 1060 IV i AKMK, sygn. AV 26, 48.
} 
niesieniu do niniejszego artykułu szczególnie istotny jest jego początkowy fragment odnoszący się do ,archiwum kieleckiego Kajetana Sołtyka”.

W 1765 r. sporządzając relację prezentującą stan diecezji krakowskiej, biskup stwierdził, iż „dom mojej rezydencji to 7 pałaców i zamków w diecezji, ale szczególniejsze, gdzie zwyczajnie przebywam to Kraków i Kielce"13. Ta interesująca uwaga, zapisana przez ordynariusza po ok. 17 latach swego krakowskiego pontyfikatu, doskonale wpisuje się w ustalenia badaczy wskazujących na istotną rolę Kielc jako jednej z głównych siedzib biskupich w Polsce ${ }^{14}$. Odnosząc się do relacji Kajetana Sołtyka, jego kontakty z miastem nad Silnicą należy podzielić na cztery okresy, tj. pierwsze lata na stolicy biskupiej (1758-1767), następnie czas zesłania do Smoleńska i Kaługi, gdy kontakty z miastem były mocno ograniczone (1767-1773) ${ }^{15}$, okres po powrocie z Rosji i kontynuacja aktywności duszpasterskiej (1773-1782), a w końcu wydarzenia po 1782 r., kiedy Kielce stały się stałą rezydencją uznanego za niepoczytalnego i chorego umysłowo ordynariusza. Niestety, brak zasadniczych badań nad funkcjonowaniem kancelarii biskupów krakowskich, także w czasach Sołtyka, nie pozwala dziś na jasne określenie zmian, jakie zachodziły w działaniu jego kancelarii w poszczególnych okresach i wreszcie, jak zmienily się po 1782 r. Poza oczywistym zminimalizowaniem prerogatyw i obowiązków, które przejął po nim ówczesny biskup płocki Michał Jerzy Poniatowski, Sołtyk nadal utrzymywał wystawny dwór i zapewne jakąś formę kancelarii, o której charakterze można tylko domniemywać ${ }^{16}$.

Brak rejestrów osobowych dworu Kajetana Sołtyka nie pozwala na jednoznaczne i szczegółowe odtworzenie liczebności dworzan oraz ich osobowej identyfikacji. Z tego samego powodu trudno ocenić liczbę i charakter pracowników kancelarii biskupiej, która z perspektywy niniejszych rozważań jest szczególnie istotna. Maria Czeppe wskazywała w swoich badaniach, że dwór ordynariusza krakowskiego mógł liczyć kilkaset osób, a ogólna liczba jego „pracowników” sięgała tysiąca ${ }^{17}$. Ustalenia te powtórzył w swoich pracach Piotr Starzyk, tworząc jednak bardziej szczegółowy obraz dworu Kajetana Sołtyka, będącego jednocześnie zespołem jego współpracowników towarzyszących biskupowi podczas licznych podróży ${ }^{18}$. Chęć wyodrębnienia grup dworzan pełniących funkcje w po-

${ }^{13}$ Relacje o stanie diecezji krakowskiej 1615-1765, wyd. W. Müller, Lublin 1978, s. 175.

${ }^{14}$ Warto tu przytoczyć pracę M. Pieniążek-Samek, Tributum gratitudinis reddo. Fundacje artystyczne na terenie Kielc w XVII i XVIII wieku. Studium z historii kultury, Kielce 2005, pass.; J. Kuczyński, Kielecka rezydencja biskupów krakowski, „Rocznik Muzeum Narodowego w Kielcach”,15 (1986/1987) s. 15-56; J.L. Adamczyk Wzgórze Zamkowe w Kielcach, Kielce 1991, passim.

${ }^{15}$ Wówczas też doszło do zrabowania i dewastacji pałacu biskupiego w Kielcach, zob. W. Kęder, Biskup Kajetan Soltyk i jego aktywność w sprawie dysydenckiej w 1766-1767 roku w świetle korespondencji dyplomatów papieskich, „Studia Sandomierskie”, 20 (2013) nr 2, s. 28.

${ }^{16}$ M. Czeppe, Soltyk Kajetan Ignacy h. własnego (1715-1788),Polski Stownik Biograficzny (dalej: PSB), t. 40, red. H. Markiewicz, Warszawa 2000-2001, s. 388-403.

${ }_{17}$ Taż, Na dworze biskupa Kajetana Soltyka, w:Patron i dwór. Magnateria Rzeczypospolitej w XVI-XVIII wieku, red. E. Dubas-Urwanowicz, J. Urwanowicz, Warszawa 2006, s. 226-228.

${ }^{18}$ P. Starzyk, Dworzanie i wspótpracownicy biskupa Kajetana Ignacego Soltyka w latach 17591788, „Studia Muzealno-Historyczne”, 3 (2011) s. 116-120. 
szczególnych rezydencjach, określenie ewentualnych przepływów osobowych lub wyodrębnienie stałego zespołu pełniącego swoje obowiązki bezpośrednio przy ordynariuszu wymaga dalszych szczegółowych badań. W związku z sytuacją zdrowotną Sołtyka można jednak mówić ostałym „kieleckim dworze” biskupa, który ukształtował się po 1782 r. Wówczas towarzyszyło mu ok. 80 osób różnej profesji $1^{19}$.

Zapewne także wcześniej kielecka rezydencja stawała się centrum politycznym oraz miejscem, skąd Sołtyk zarządzał swoją diecezją. Świadczą o tym choćby liczne dokumenty, odezwy i okólniki wydane nad Silnicą. Dnia14 stycznia 1764 r. biskup opublikował tam Proces o szczęśliwy sukces sejmu konwokacyjnego i elekcyjnego oraz listy to szlachty województwa lubelskiego. Dnia 4 października 1764 r. powstał w Kielcach okólnik wzywający do modlitw nad pomyślnością sejmu koronacyjnego. Drugim korpusem źródeł wskazujących na częstotliwość tamtejszego rezydowania biskupa jest zachowana w znacznym stopniu korespondencja przechowywana w zbiorach Biblioteki Książąt Czartoryskich, Zakładu Narodowego im. Ossolińskich we Wrocławiu czy Biblioteki Narodowej w Warszawie. Już pobieżna lektura pozwala stwierdzić, iż biskup spędzając tam czas, zajmował się sprawami bieżącej polityki diecezjalnej i państwowej ${ }^{20}$.

Można zatem przypuszczać, iż był to kolejny powód dla utrzymywania w Kielcach, w określonym wymiarze, stałego zaplecza kancelaryjnego, w którego skład wchodzili sekretarze, regensi, protonotariusze i notariusze publiczni ${ }^{21}$. W innym wypadku należałoby założyć, iż Sołtyk korzystał wyłącznie z podróżującej wraz z nim kancelarii zadwornej i jej zespołu, co przy częstych pobytach nad Silnicą byłoby logistycznie nieszczególnie atrakcyjnym rozwiązaniem. Odrębną kwestią jest natomiast sprawa archiwum, które zapewne ze względów praktycznych przechowywano w stałym miejscu. Takie rozwiązania stosowane były bowiem dla „wędrujących” dworów ordynariuszy, przebywających dłużej lub krócej w poszczególnych rezydencjach ${ }^{22}$. Pośród wymienionych przez Starzyka dworzan biskupa próżno jednak szukać osoby odpowiedzialnej za prowadzenie archiwum, wobec czego można sądzić, iż zadanie to leżało w ogólnych kompetencjach kancelarii, której archiwum było naturalnym elementem.

Wydaje się, że dokumentacja, która powstała w samych Kielcach oraz okolicznych dobrach była przechowywana początkowo na miejscu, a dopiero po pewnym czasie przekazywana do stołecznego Krakowa. Proces ten już w 1784 r. przedstawiał Franciszek Potkański w liście do bpa M.J. Poniatowskiego, twierdząc, iż

${ }^{19}$ Czeppe, Na dworze biskupa Kajetana Soltyka, s 227.

${ }^{20}$ K. Rudnicki, Biskup Kajetan Sottyk 1715-1788, Warszawa 1906, s. 261-265.

${ }^{21}$ Spośród znanych sekretarzy biskupa Sołtyka warto wskazać na duchownych: Grzegorza Kułagowskiego, Karola Lochmana, Franciszka de Lisle, Krzysztofa Ćwiertniewskiego oraz świeckich: Florentyna Czaplickiego, Leona Chylewskiego, Joachima de Kalnassy i Józefa Kownackiego, którzy występowali przy ordynariuszu podczas jego pobytów w Kielcach. Nieco odrębną grupę stanowili sekretarze wyznaczeni do prowadzenia korespondencji zagranicznej jak Horacy Cantini czy Franciszek Kwietniowski.Starzyk, Dworzanie i wspótpracownicy biskupa, s. 121-125.

${ }^{22}$ Tamże. 
Kamienica, w której jest archiwum i więzienie nazwane Niedźwiedź jest własna officii od wieków na to przez biskupów i Kapitułę destynowana. W niej jest archiwum aktów biskupich i konsystorskich. Nawet z Kielc akta tamtejsze tu bywają przewożone, bo tu jest archiwum generalne ${ }^{23}$.

Była to jednak procedura długotrwała, gdyż jeszcze w 1796 r. dokumenty biskupa Sołtyka z lat 1759-1775 pozostawały w kancelarii kieleckiej, a raczej tamtejszym archiwum ${ }^{24}$. W wyniku przeprowadzonej w XVIII wieku przebudowy kolegiaty kieleckiej archiwum umiejscowiono we wschodniej części świątyni, blisko prezbiterium i kapitularza ${ }^{25}$. Zastanawiające jest, czy również kancelaria biskupa korzystała z tego pomieszczenia. Bardziej prawdopodobne wydaje się jednak sytuowanie jej wraz z archiwum w nieodległym pałacu biskupim.

Inwentarz zamieszczony w Kompendium Kielcensis obrazuje zatem stan zasobu tamtejszego archiwum, zgromadzonego lub wytworzonego przez kancelarie biskupa Sołtyka. O ile data jego sporządzenia pozostaje w sferze domniemań, warto pochylić się nad charakterystyką zasobu, która wnosi także szereg danych na temat samej kancelarii biskupiej. Przechowywane akta porządkowano w systemie rzeczowym, układając dokumentację w tzw. fascykuły oraz akt luźne. Każdy fascykuł zawierał prawdopodobnie kompletny materiał dotyczący zrealizowanej sprawy. Można tam wyróżnić 13 takich fascykułów oraz tworzący osobną jednostkę inwentarz archiwum kapituły krakowskiej z 1750 r. Bieżącą pracę kancelarii i samego archiwum prezentują ponadto liczne dopiski i komentarze sporządzane w odniesieniu do poszczególnych zapisów zawartych w kompendium, potwierdzając jednocześnie fakt istnienia tamtejszego archiwum jako odrębnej ,instytucji”.

Przykłady tego widnieją na marginesie kart 114v: „Notandum według tego Summaryuszu ${ }^{26}$ ac do Znaku y Paragrafu $\S$ tych Dokumentow in archivo w Kielcach Jo Xcia Imci niemasz tylko to iest vertigium że mają bydz ad manus W. Przyłęckiej”[!]; 300: „Ex Libris Relationum Castri Cracoviensis Wyiąc potrzeba”[!]; 126: „Aż do tego Znaku jako pater na Marginesie a principio Sumaryuszu położonego znak $\S$ in Archivo w Kielcach niemasz tych Dokumemtów które u W. Przyłęckiej ad manus mają być adnotat.” [!], czy notatka „Sumaryusz Roczny trzech kluczow Xięstwa Sierwierskiego to jest Siewierza, Sławkowa y Koziegłow na Summe złotych pol. 61787 g 3 wyprowadzony, y do archivum JO Xcia Załuskiego biskupa Krakow[ensis] podany [!]” umieszczona na karcie 141v.

Pośród wymienionych zapisków szczególnie istotne są te, które wskazują na przemieszczanie dokumentacji poza i do archiwum kieleckiego, a także na prowadzone w jego obrębie kwerendy. Choć trudno datować wspomniane notatki, obrazują istotę funkcjonowania instytucji archiwum, niezmienną aż do dziś, czyli za-

${ }^{23}$ Cyt. za: J. Kracik, Zasoby Archiwum Kurii Metropolitalnej w Krakowie, „Analecta Cracoviensia", 9 (1977) s. 487-488.

${ }^{24}$ Tamże, s. 488.

${ }^{25}$ M. Pieniążek-Samek, Przemiany kolegiaty (obecnie katedry) kieleckiej w epoce baroku w świetle inwentarzy, część III, wiek XVIII, „Rocznik Muzeum Narodowego w Kielcach”, 20 (2000) s. 82.

${ }^{26}$ Sumariusz dokumentów dot. wsi Mierzowice i Chruszczobród należących do Zuzanny Myszkowskiej 
bezpieczanie, przechowywanie, opracowywanie i udostępnienie zdeponowanych archiwaliów.

Zakres chronologiczny zasobu rozciąga się od 1276do 1758r., ze zdecydowaną przewagą materiałów XVIII-wiecznych. Należy jednak wspomnieć, iż nie wszystkie pozycje opatrzone są datami, co nie wyklucza ich późniejszej metryki. Rok 1758 sugeruje zaś włączenie do archiwum bpa Kajetana Sołtyka materiałów wytworzonych przez jego poprzedników, szczególnie przez bpa Andrzeja Stanisława Załuskiego, który zmarł 16 grudnia tegoż roku. Episcopalia tworzące zasób kieleckiego archiwum biskupa stanowią zatem również ilustrację działalności poprzednich ordynariuszy diecezji, ze szczególnym uwzględnieniem bpa Załuskiego. Nie są to jednak dokumenty tożsame z episkopaliami przechowywanymi dziś w Archiwum Kurii Metropolitalnej wKrakowie ${ }^{27}$. Ich biskupią proweniencję zdaje się natomiast potwierdzać charakter opisanego zasobu, oddający niemal pełne spektrum działalności ordynariusza jako zarządcy diecezji i własnych dóbr stołowych. Obok spraw sądowych, liturgicznych, ekonomicznych występują tam odpisy aktów fundacyjnych, dokumentacja odnosząca się do procesów kanonicznych, wizytacje biskupie czy akta konsystorskie lub dokumenty dotyczące działania kościoła św. Stanisława w Rzymie. W całym kompendium są ponadto informacje o innych dokumentach znajdujących się w kieleckim archiwum, jak oprawiony w białą skórę kodeks zawierający inwentarz klucza jangrodzkiego (k. 176) oraz inwentarz generalny klucza uszewskiego(k. 240).

$\mathrm{W}$ przypadku niektórych zamieszczonych w inwentarzu dokumentów istnieje możliwość identyfikacji lub wskazania okoliczności ich wytworzenia. Przykładami tego mogą być widniejące pod numerem pierwszym instrukcje dla obchodów Wielkiego Jubileuszu. Wydaje się, że można je utożsamić z trwającymi od 23 czerwca do 28 lipca 1776 r. uroczystościami, na które zgodę wydał papież Pius VI oraz biskup krakowski Kajetan Sołtyk. W obchody włączyli się ponadto dominikanie z Litwy oraz benedyktyni ze Św. Krzyża, cystersi z Wąchocka, bernardyni z Karczówki i Świętej Katarzyny - czyli opactwa i klasztory znajdujące się w okolicach $\mathrm{Kielc}^{28}$.

Nieco więcej faktów można ustalić w związku z dokumentacją gromadzoną dla celów procesów kanonizacyjnych. W przypadku prób wyniesienia na ołtarze św. Kingi działania w tym celu podejmowano już na przełomie XVII i XVIII wieku. Ich intensyfikacja nastąpiła w 1733 r., kiedy starosądeckie klaryski podjęły starania o uznanie ich patronki za świętą. Efektem ich zabiegów była zgoda papieża Benedykta XIV na rozpoczęcie procesu kanonizacyjnego i wezwanie, które ojciec św. skierował w tej sprawie do kardynała Jana Lipskiego, rezydującego w tym czasie wielokrotnie w Kielcach. Dnia 7 sierpnia 1742 r. kardynał wy-

${ }^{27}$ Przeprowadzona prze mnie wstępna kwerenda w Archiwum Kurii Metropolitalnej w Krakowie nie przyniosła w tym względzie szczególnie istotnych odkryć. Wydaje się, że właściwe byłoby przeprowadzenie szczegółowego skolacjonowania treści kieleckiego archiwum biskupa Sołtyka z aktami kancelarii biskupich znajdujących się w AKMK, ze szczególnym uwzględnieniem sygnatur AEp. 73-AEp. 96, co - mam nadzieję - uda mi się wykonać w niedalekiej przyszłości.

${ }^{28}$ M. Pieniążek-Samek, Życie religijne $w$ parafii kolegiackiej $w$ Kielcach $w$ XVII-XVIII wieku. Zarys problematyki, „Rocznik Muzeum Narodowego w Kielcach”, 22 (2006) s. 164. 
znaczył sędziów mających rozstrzygać w procesie o świętości, cnotach i cudach bł. Kingi. Po jego śmierci w 1746 r. nad przebiegiem procesu czuwał oficjał kolejnego zasłużonego dla Kielc biskupa krakowskiego -Andrzeja Załuskiego, Marcin Żeromski, który w 1749 r. dostarczył wymagane dokumenty do Rzymu. Niekompletność materiałów powodowała, iż Kongregacja ds. Obrzędów w Kurii Rzymskiej domagała się ich uzupełnienia, co czyniono do 1762 r., a więc także w czasach pontyfikatu Kajetana Sołtyka. Bezpośredni związek tej dokumentacji z Kielcami nie jest w pełni jasny. Niewykluczone, iż były to akta pozostałe po zaangażowanym $\mathrm{w}$ proces kanonizacyjny kardynale Lipskim, zmarłym w Kielcach 20 lutego $1746 \mathrm{r}$. Możliwe także, iż dokumenty były gromadzone dopiero przez Andrzeja Załuskiego i Kajetana Sołtyka, gdyż stanowiły materiały konieczny dla dalszych starań o uznanie świętości bł. Kingi ${ }^{29}$.W przypadku aktów dotyczących procesu kanonizacyjnego Jana Kantego ( $\mathrm{nr} 8$ ) były to prawdopodobnie dokumenty gromadzone już w czasie pontyfikatu biskupa Sołtyka. Mimo iż badacze interesujący się sylwetką ordynariusza nie przypisywali mu w tej kwestii żadnej znaczącej roli, należy stwierdzić fakt pozytywnego zakończenia procesu w 1767r., gdy ten funkcję biskupa krakowskiego pełnił już blisko dekadę ${ }^{30}$.

Swoją literaturę mają także związki biskupów krakowskich z kościołem św. Stanisława w Rzymie, do czego odnoszą się dokumenty widniejące pod numerem 3. Biskup krakowski Andrzej Stanisław Załuski, będąc z racji swej godności protektorem tegoż kościoła, określanego jako Kościół Narodowy, wydał w 1757 r. statut określający obowiązki i prawa biskupów krakowskich względem tej świątyni. Statut ten potwierdziła na wniosek bpa Kajetana Sołtyka kapituła krakowska w $1763 r{ }^{31}$ Interesująca jest także pojawiająca się w inwentarzu postać czcigodnego Carolusa Albanusa. Można domniemywać, iż jest to odniesienie do Allesandro Albaniego, kardynała w latach 1721-1779, brata Annibale Albaniego kardynała protektora Polski w latach 1712-1751, lub właśnie do Annibalego, zakładając pomyłkę w odnotowanej dacie. W takim przypadku postać „Carolusa” powstałaby w wyniku pomyłki pisarskiej autora ${ }^{32}$. Równie zagadkowe są niektóre daty zawarte $\mathrm{w}$ inwentarzu, jak w przypadku informacji o dokumentach wizytacyjnych z 1753 r. Do dziś bowiem zachowane są i znane badaczom akta wizytacyjne dekanatu nowosądeckiego z lat 1723-1728, prepozytury kieleckiej oraz dekanatów tarnowskiego i wojnickiego z 1748 r. ${ }^{33}$

Można natomiast zidentyfikować kilka wpisów dotyczących fundacji oraz przywilejów opisanych w inwentarzu. Przykładem może być fundacja „Bidzińska”, której współprotektorem był biskup Sołtyk. Została ona powołana jeszcze

${ }^{29}$ J. Pabis, O kanonizację bt. Kunegundy, Tarnów 1947, s. 18-22; J. Gierowski, Lipski Jan Aleksander h. Grabie (1690-1746), PSB, t. 17, red. H. Markiewicz, Wrocław 1972, s. 430.

${ }^{30}$ Rudnicki, Biskup Kajetan Sottyk, s. 199; Czeppe, Sottyk Kajetan Ignacy h. własnego (17151788), s. 386-404.

${ }^{31}$ B.S. Kumor, Dzieje diecezji krakowskiej do roku 1795, t. 1, Kraków 1998, s. 607-609.

${ }^{32}$ M. Śladowska, Polityka Augusta II wobec Kościoła katolickiego w Polsce oraz relacje z kuria rzymska w świetle korespondencji króla z kardynatem Annibalem Albanim w latach 1716-1721, „Kronika Zamkowa”,1-2 (2009) s. 109-142.

${ }^{33}$ Kumor, Dzieje diecezji krakowskiej, t. 1, s. 55. 
w 1693 r. na rzecz wykupywania jeńców z tureckiej niewoli. Jej fundatorem był właściciel dóbr Stefan Bidziński, kasztelan sandomierski i strażnik wielki koronny ${ }^{34}$. Opisany pod numerem 13.29 przywilej, a raczej dokument erekcyjny Kolegium Muzyków, można utożsamić z aktem wydanym przez biskupa krakowskiego Marcina Szyszkowskiego 20 stycznia 1619r., potwierdzonym bullą papieską Pawła V z 29 kwietnia $^{35}$. Zdecydowanie trudniejsza jest weryfikacja enigmatycznie brzmiących zapisów jak w przypadku numerów 3, 5, 6, 10, 12, 13.2 czy 13.24, a także ich obecnego umiejscowienia w zasobach bibliotek lub archiwów. W tym przypadku konieczna będzie odpowiedź na podstawowe pytanie - czy zawarte w inwentarzu materiały wciąż istnieją? Wszystko to powoduje, że odtworzenie dziejów archiwum kieleckiego biskupa Sołtyka jest zadaniem niezwykle trudnym i wymagającym bardzo wnikliwych kwerend, pozostając tym samym aktualnym postulatem badawczym.

Celem niniejszego artykułu było wskazanie na jedno z istotnych i pomijanych dotąd w badaniach źródeł, ukazujących funkcjonowanie kancelarii zadwornej biskupa Kajetana Sołtyka, archiwum biskupiego i miejsca Kielc w systemie administrowania diecezją krakowską w drugiej połowie XVIII wieku. Przyczynkowy charakter pracy oraz oddanie w formie aneksu treści kieleckiego archiwum bpa Sołtyka otwiera dyskusję nad powyższym zagadnieniem, które w przyszłości znajdzie swoje właściwe rozwinięcie. Przeprowadzone dotychczasowe kwerendy z całą pewnością nie wyczerpują badawczo przedstawionego tematu, jednakże pozwalają na zaproponowanie kilku wniosków. Po pierwsze należy uznać, iż w kieleckiej rezydencji biskupów krakowskich mieściło się archiwum gromadzące dokumentację będącą efektem prac kancelarii biskupiej, przynajmniej z lat 1759-1775, a przechowywanej tam jeszcze w 1796 r. Pewien obraz pracy ów kancelarii można natomiast uzyskać, analizując rzeczowy układ spraw, oraz ich różnorodność tematyczną. Interesującym efektem prowadzonych kwerend wydaje się natomiast samo odnalezienie owego „kompendium”, wskazującego na rozbudowany system kancelaryjny, jakim dysponowali biskupi krakowscy. Być może przyszłe badania pozwolą odnaleźć kolejne kompendia, a następnie porównać ich zawartości i sposobu przygotowania. Ostatnią kwestią, na którą warto zwrócić uwagę, to swego rodzaju decentralizacja zarządzania terytorium diecezji przez jej ordynariuszy. Prowadzenie spraw biskupstwa niemal w systemie „rex ambulans" pozostawało niejako w kontrze do coraz bardziej scentralizowanego, biurokratycznego modelu administracji, właściwego dla końca drugiej połowy XVIII wieku.

Zamieszczony poniżej inwentarz archiwum kieleckiego biskupa Kajetana Sołtyka został przygotowany zgodnie z zasadami współczesnych wydawnictw źródłowych. Dokonano zatem gramatycznego ujednolicenia zapisów, wskazania omyłek pisarskich, a także rozwinięcia wszystkich użytych abrewiacji. Stosowane zamienne „„” oraz „I” zostało ujednolicone do „I”. Nazwy własne i tytuły zachowano w oryginalnym zapisie, podając ich współczesne brzmienie w przypisach.

\footnotetext{
${ }^{34}$ K. Piwarski, Bidziński Stefan, PSB, t. 2, red. H. Markiewicz, Kraków 1936, s. 20-22.

${ }^{35}$ Kumor, Dzieje diecezji krakowskiej, t. 1, s. 403.
} 
Układ inwentarza został zachowany w swojej oryginalnej formie, podobnie jak wszystkie pozostałe elementy. Zachowanie określonych standardów wydawniczych w znacznym stopniu umożliwiła instrukcja Kazimierza Lepszego ${ }^{36}$.

\section{ANEKS ŹRÓDLOWY}

[k.6]

EPISCOPALIA et DIAECESANA In Archivo Kielcensi J[aśnie] O[świeconego] X[ię]cia I[ego]m[oś]ci Soltyka Biskupa Krakowę[skiego], ad p[rae]sens reperibilia

1 mo Fasciculus, in quo continet[ur] informatio Devotionis Quadraginta Horarum, et Iubilaei Magni.

2do Fasciculus, in quo est Processus Canonicationis B[eatae]Cunegundis Reginae Poloniae circa Annum 1742.

3tio Fasciculus, in quo Bullae Summorum Pontificum et Epistolae expeditionis Romanae.

4to Fasciculus, in quo reperiuntur variae Informationes de Ecclesia Nationali in Urbe, scilicet transumpta Statutorum, Proventuum at[que] debitorum. Tum visitatio ultima dictae Ecclesiae Nationalis p[er] R[evere]nd[u]m] Carolum Albanum $^{37} \mathrm{~A}[\mathrm{nn}] \mathrm{o} 1757$ peract[a].

5to Fasciculus, in quo extant Puncta a Capitulo, et ad Capitulum Eclesiae cathedralis Cracovien[sis], ac varia informationes de Coadiutoriis, atq[ue] deputando Concionatore.

6to Fasciculus, in quo inveniunt[ur]Visitationes, Capellarum, Altarium, Vicariorum, Mansionariorum, Psalterietarum et aliorum Ecclesiae Cathedralis Cracovien[sis].

7mo Fasciculus, in quo sunt varii Status Ecclesiarum, Collegiatarum et Visitationes earum, nempe Kielcen[sis], Lublinen[sis], Neosandecen[sis], Tarnovien[sis], Voynicen[sis] de A[nn]o 1753 et aliis.

8 vo Fasciculus, in quo Statuta Antiquea Collegii Maioris, tum Instructio pro rite construendo Processu super miraculis novis B[eati] Joannis Cantii.

[k.6v]

9no Fasciculus continens in se Privilegia, Statuta, Inscriptiones et alia Documenta ad Collegium Iuridicum et Contubernium Iuris peritorum ${ }^{38}$ Universit[atis] Cracovien[sis] pertinen[tia].

10 Fasciculus, in quo sunt Iura et Documenta Seminariorum Diaecesis Cracovien[sis].

${ }^{36} \mathrm{~K}$. Lepszy, Instrukcja wydawnicza dla źródet historycznych od XVI w. do pot. XIX w., Warszawa 1953.

${ }^{37}$ Prawdopodobnie odnosi się to do Allesandro Albaniego, kardynała w latach 1721-1779 lub jego brata kardynała protektora Polski, zakładając pomyłkę w podanej dacie.

${ }^{38}$ Zapewne powinno być „Iurisperitorum”. 
11 Fasciculus cum Juribus et Documentis variorum Monasteriorum et Conventuum Hospitalisq[ue] S[ancti] Spiritus.

12 Fasciculus, in quo sunt haec Compendium Jurium, Suffraganeat[us]

Cracovien[sis], Edicta [con]tra Judaeos, et alia Spiritualia, seu informatio de Contribu[tio]nibus Capitalibus.

13. Fasciculus, in quo continentur sequentia:

1) Litterarum Romanarum Indulgentias in se continentium Congregationi Missionisservien[tia] Ingrossatio ad acta Consistorii G[eneralis] Janovien[sis] 1748.

2) Approbatio in Pargameno scripta Privilegii Collationis ad varios Canonicatus et Ecclesias Parochiales Capitaneis Clavium Epp[isco]palium servien[tium].

3) Rescriptum $\mathrm{Sa}$ [crae] $\mathrm{R}$ [egi]ae M[aiesta]tis in Causa Canonicatus Cathedralis Cracoviensis Fundi Gorka ${ }^{39}$ protunc controversi.

4) Rescriptum $\mathrm{Sa}$ [crae] $\mathrm{R}$ [egi]ae M[aiesta]tis revocatorium Litterarum protectionalium a $\mathrm{Sa}$ [crae] $\mathrm{R}$ [egi]ae M[aiesta]te obtentarum pro Parte Infidelis Aaron, Michaelis Colchorii Medicina D[octo]ris ${ }^{40} 1758$.

5) Ordinatio Iudiciorum in qua Causis Diaecesanis in curia et ConsistorioG[enera]li Cracovien[sis] agitandis Dies distincti assignant[ur] 1758.

6) Submissio Provisoris, Praefecti, Procurat[oris] Seminarii Epi[scop]alis, qui post apprehensam Possessionem Typographiae, Rubricellas seu Directoria pro tota Diaecensi, tum et exemplaria Devotionis Quadraginta Horarum pro ecclesiis intra, et extra Maensa existen[tium]edere quovis $\mathrm{A}[\mathrm{nn}]$ o proprio Sumptusse se obstrinxerunt A[nn]o 1758.

7) Commissio in Personam G[enerosi] Komorowski ${ }^{41}$ ad revidenda Pasculi Monialium Sandecen[sium] sub Clavi Svinarscen[sis] $]^{42}$ existen[tis] 1738.

8) Privilegium Em[inentissi]mi Cardin[alis] Lipski super Decima MensaeEpiscopalis p[rou]t villam Zdrząbin ${ }^{43}$ Conventui Camaldulen[si] prope Rytviany ${ }^{44}$ Diaecesis Cracovien[sis] ad tempus Servien[tis] de A[nn]o 1743.

[k. 7]

9) Decretum ad iudica[ti]onis Decimarum ad non[n]ullas Ecclesias et ad Mensam Ep[isco]palem ex medietate Villae Maydan ${ }^{45} 1756$.

${ }^{39}$ Wydaje się, że należy identyfikować tę miejscowość z dzisiejszą Górką Pabianicką w pow. pabianickim, która w XVIII wieku przeszła w ręce kapituły krakowskiej. W 1763 r. instalowany na kanonię krakowską fundi Górka był bratanek bp. Kajetana Sołtyka - Maciej Sołtyk, zob. M. Czeppe, J. Śmiałowski, Sołtyk Maciej Kajetan h. własnego (zm. 1804), kanonik krakowski, sekretarz w. kor., w: PSB, t. 40, Wrocław 2000-2001, s. 404.

${ }^{40}$ Postaci nie udało się zidentyfikować.

${ }^{41}$ Postaci nie udało się zidentyfikować.

${ }^{42}$ Klucz świniarski, jako jeden z kluczy gospodarczych biskupów krakowskich, którego centralną miejscowością było Świniarsko, zlokalizowany był na terenie dzisiejszego powiatu nowosądeckiego.

${ }^{43}$ Zapewne wieś Zrębin, obecnie w powiecie staszowskim, woj. świętokrzyskim.

${ }^{44}$ Rytwiany, wieś w powiecie staszowskim, woj. świętokrzyskim.

${ }^{45} \mathrm{~W}$ związku ze znaczną liczbą przysiółków, wsi i miejscowości o takiej nazwie wskazanie na konkretną osadę pozostaje w sferze domysłów. 
10) Connotatio Decimarum ad Mensam Ep[isco]palem spect[antium] sub variis Parochiis reperib[ilis] A[nn]o 1747 fact[a]?

11) Copia Mandati S[erenissi]mi Regis Stephani A[nn]o 1577 ad Capitaneos quatenus Decimas reddant.

12) Commissio in Residentia Plebanali Muszynen[sis] 1751 qua mediante res derelictae $\mathrm{p}[\mathrm{os}] \mathrm{t}$ defunctum Ill[ust]rem Kaczorski Ecclesiarum ${ }^{46}$ in Grybow ${ }^{47}$ Preapositum et in Muszyna Curatum sunt dispositae.

13) Transla[tio]nes de Fundo in Fundum $P$ [atrum] praelatorum, et Canonicorum Ecclesiae Cathed[ralis] Cracovien[sis] ab A[nn]o 1526 ad 1749 Annum synoptice connot[atae].

14) Copia decreti V[enerabilis] Capituli Cracovien[sis] Cessionis Iuris Patronatus ad Ecclesiam Parochialem in Oppido Czamierniki ${ }^{48}$ servien[tis] in Personam Ill[ustri]s D[omi]ni Hubicki [!] Palatini Podoliae ${ }^{49}$ in A[nn]o 1731 fac$\mathrm{t}[\mathrm{i}]$.

15) Status antiquus Electionum Archidiaconorum Zavichosten[sium] in Capitulo.

16) Copia Erectionis Ecclesiae Lignea sub Nomine et Invocatione Misericordiae DEI ac Patrocinio B[eate] V[irginis] M[ariae] in Villa Episcopali Zabierzow $^{50}$ dic[ta] sub Parochia Wawrzencinen ${ }^{51}$ [sis] post Vistulam sita 1741.

17) Copia Litterarum Erectionis PraeposituraeEcclesiaeOppidi Sienno 1452. Item Copia Erectionis seu Renova[ti]onis Erectionis Ecclesiae Siennen[sis] 1749 .

18) Incorporatio Beneficii in Gorczyce ${ }^{52}$ per $S[$ acram] $R$ [egiam] $M$ [aiestatem] com[m]unitati Vicariorum Sandomierien[sium] A[nn]o 1530.

19) Summarium Iurium et Privilegiorum villae Swiątniki ${ }^{33}$ et aliis in Palatinatu et Districtu Sandomierien[sis] iacen[tium] a S[erenissi]mi Regibus Poloniarum collatorum ac in Archivo dictae villae asservatorum ab A[nn]o 1276 ad Annum 1744.

[k. $7 \mathrm{v}]$

20) Inter Praepositum S[ancti] Spiritus et Provisores Hospitalis S[ancti] Spiritus Cracovien[sis] ratione intro contentorum concordia in Officio Consist[orii] G[enera]lis 1529.

${ }^{46}$ Zapewne odnosi się to do ks. Stanisława Kaczorowskiego proboszcza w Muszynie zm. w $1751 \mathrm{r}$. nieopodal miasteczka Grybów.

${ }^{47}$ Miasto Grybów w pow. nowosądeckim.

${ }^{48}$ Czemierniki miasto na Lubelszczyźnie w pow. radzyńskim.

49 Jest to zapewne błąd pisarza, w latach 1706-1736 wojewodą podolskim był bowiem Stefan Humiecki (Urzędnicy podolscy XIV-XVIII wieku. Spisy, oprac. E. Janas, W. Kłaczewski, J. Kurtyka, A. Sochacka, Kórnik 1998, nr 661, s. 149).

${ }^{50}$ Zapewne wieś: Zabierzów Bocheński, dziś w pow. wielickim.

${ }^{51}$ Wawrzeńczyce, obecnie wieś w pow. krakowskim.

${ }^{52}$ Być może wieś Gorzyce, położona ok. $10 \mathrm{~km}$ od Sandomierza, dziś w pow. tarnobrzeskim.

${ }^{53}$ Zapewne wieś Świątniki w gminie Obrazów, powiat sandomierski. 
21) Copia Erectionis Archiconfraternitatis Philadelphiae ${ }^{54}$ Praesbyterum in Districtu Sandecen[sis] de A[nn]o 1553 erect[ione].

22) Memoriale seu supplicatio ad S[anctis]simum $D[$ eum] ex Parte $C[e] 1[$ si $]$ ssimi Principis Łubiński ${ }^{55}$ de Pallio italice script[um].

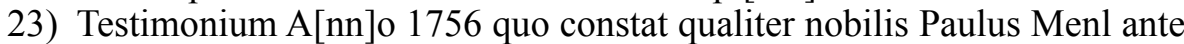
contractum Matrimonium cum Pudica Magdalena Catholica moderna consorte sua subsubmisit se amplecti Fidem Romanam Catholicam, et abiurare Lutheranos $^{56}$. Item Testimonium alterum ex Libris Copulatorum Insignis Ecclesia Coll[egi]atae et Parochialis Varsavien[sis], quo demonstrate Matrimonium esse benedictum inter supra dictos sponsus 1756.

24) Connotatio Fanorum in Diaecesi Cracovien[sis].

25) Copia ordinationis Mechanici Ord[inis] Cracoviae videlicet Contuberniorum omnium intra ex extra Civitatem existen[tium] per CommissariosS[acrae] R[egiae]M[aiesta]tis A[nn]o 1747 expeditae.

26) Informa[ti]o Fundationis Bidzinsciana ${ }^{57} \mathrm{p}[\mathrm{ro}]$ Redemptione Captivorum et Calculatio Clavis Januszovicen[sis] A[nn]o 1757.

27) Littera Responserie Manu R[evere]nd[is]simi Rresidensis de Data earum [d]ie 12 Junii 1758 in Generali Capitulo ad C[elsissi]mum D[omi]num p[iae] $\mathrm{m}$ [emoriae] ep[isco]pum cracovien[sis] directae.

28) Copia Statutorum V[enerabilis] Capitulo Cracovien[sis] A[nn]o 1732 collectae.

29) Extractum Privilegii Fundationis Collegii Musicorum in Ecclesia Cathedrali Cracovien[sis] 1619.

30) Liber Compactus sub Titulo Inventarium Archivi V[enrabilis] Capitulo Cracovien[si] pro meliori Munimentorum notitia collect[us] et conscript[us] 1750 Anno.

\section{REFERENCES / BIBLIOGRAFIA}

\section{Źródla}

Archiwum Kurii Metropolitalnej w Krakowie:

Akta wizytacji biskupich, sygn. 26, 48.

Biblioteka XX Czartoryskich w Krakowie:

sygn. 1059 IV Summaryusz przywilejow w archiwum katedry krakowskiej 1757;

${ }^{54}$ Wydaje się, że zapis ten odnosi się do arcybractwa kapłańskiego pw. Bożego Ciała Chrystusa, powołanego jeszcze przez kard. Zbigniewa Oleśnickiego w Starym Sączu, którego prawa potwierdził w 1553 r. biskup krakowski Andrzej Zebrzydowski, nadając jednocześnie nowy statut. Konfraternia przyjaźni (philadelphia) miała na celu opiekę nad duchownymi w podeszłym wieku i złym stanie zdrowia.

${ }^{55} \mathrm{~W}$ tym miejscu prawdopodobnie zaszła pomyłka kopisty i zapewne odnosi się to do Kazimierza Łubieńskiego h. Pomian, biskupa krakowskiego w latach 1710-1719.

${ }^{56}$ Postaci nie udało się zidentyfikować

${ }^{57}$ Wieś Bidziny w gminie Wojciechowice, powiecie opatowskim. 
sygn. 1060 IV, Inv. Summaryusz dokumentow w arch. kieleckiem znajdujacych się. Compendium archivi Kielcensis. Episcopalia et diecesana in archivo Kielcensi JOXcia JMci Sołtyka bisk. krak. z XVIII wieku.

Catalogus codicum manu scriptorum Musei Principum Czartoryski Cracoviensis. Vol. II ed. S. Kutrzeba, Cracoviae 1908-1913.

Relacje o stanie diecezji krakowskiej 1615-1765, wyd. W. Müller, Lublin 1978.

\section{Opracowania}

Adamczyk Jan Leszek, Wzgórze Zamkowe w Kielcach, Kielce 1991.

Bobkowski Kazimierz, Kancelaria oraz dokumenty biskupów i kapituly w Kamieniu (do końca XIII w.), Wrocław 1990.

Buczek Karol, Z dziejów polskiej archiwistyki prywatnej. Archiwa XX. Czartoryskich, Kraków 1938.

Chorążyczewski Waldemar Przemiany organizacyjne polskiej kancelarii królewskiej u progu czasów nowożytnych, Toruń 2007.

Czeppe Maria, Na dworze biskupa Kajetana Sottyka, w:Patron i dwór. Magnateria Rzeczypospolitej w XVI-XVIII wieku, red. E. Dubas-Urwanowicz, J. Urwanowicz, Warszawa 2006, s. 225-230.

Czeppe Maria, Sołtyk Kajetan Ignacy h. własnego (1715-1788), w: Polski Słownik Biograficzny, t. 40, red. H. Markiewicz, Warszawa 2000-2001, s. 386-404.

Czeppe Maria, Śmiałowski Józef, Sołtyk Maciej Kajetan h. własnego (zm. 1804), kanonik krakowski, sekretarz w. kor., w: Polski Słownik Biograficzny, t. 40, red. H. Markiewicz, Wrocław 2000-2001, s. 404-406.

Gierowski Józef, Lipski Jan Aleksander h. Grabie (1690-1746), w: Polski Słownik Biograficzny, t. 17, red. H. Markiewicz, Wrocław 1972, s. 425-431.

Jurek Tomasz, Pozostałości regestru kancelarii biskupa wrocławskiego Jana Romki (1292-1301) na skrawkach makulatury przypadkiem zachowane, w: Ecclesia regnum fontes. Studia z dziejów średniowiecza, red. R. Michałowski, Warszawa 2014, s. 346359.

Kardyś Piotr, Zbiór dokumentów pergaminowych i papierowych Archiwum Diecezjalnego w Kielcach, „Z dziejów Regionu i Miasta. Rocznik Oddziału Polskiego Towarzystwa Historycznego w Skarżysku-Kamiennej”, 4 (2013) s. 35-56.

Kęder Wojciech, Biskup Kajetan Soltyk i jego aktywność w sprawie dysydenckiej w 17661767 roku w świetle korespondencji dyplomatów papieskich, „Studia Sandomierskie”, 20 (2013) nr 2, s. 21-34.

Knapek Elżbieta, Księga wpisów biskupa krakowskiego Jana Lutka z Brzezia z lat 14641471, w: Ecclesia regnum fontes. Studia z dziejów średniowiecza, red. R. Michałowski, Warszawa 2014, s. 416-425.

Kracik Jan, Zasoby Archiwum Kurii Metropolitalnej w Krakowie, „Analecta Cracoviensia", 9 (1977) 471-493.

Kuczyński Janusz, Kielecka rezydencja biskupów krakowski, „Rocznik Muzeum Narodowego w Kielcach",15 (1986/1987) s. 15-56.

Kumor Bolesław Stanisław, Dzieje diecezji krakowskiej do roku 1795, t. 1, Kraków 1998. Kumor Bolesław Stanisław, Dzieje diecezji krakowskiej do roku 1795, t. 2, Kraków 1999. Kumor Bolesław Stanisław, Dzieje diecezji krakowskiej do roku 1795, t. 3, Kraków 2000. Lepszy Kazimierz, Instrukcja wydawnicza dla źródet historycznych od XVI w. do poł. XIX w., Warszawa 1953. 
Łossowski Janusz, Kancelaria grodzka chetmska od XV do XVIII wieku. Studium o urzedzie, dokumentacji, jej formach i roli $w$ życiu społeczeństwa staropolskiego, Lublin 2004.

Łossowski Janusz, Kancelarie miast szlacheckich województwa lubelskiego od XV do XVIIIwieku, Lublin 1997.

Pabis Jan, O kanonizację bt. Kunegundy, Tarnów 1947.

Pieniążek-Samek Marta, Przemiany kolegiaty (obecnie katedry) kieleckiej w epoce baroku w świetle inwentarzy, część III, wiek XVIII, „Rocznik Muzeum Narodowego w Kielcach", 20 (2000) s. 11-84.

Pieniążek-Samek Marta, Tributum gratitudinis reddo. Fundacje artystyczne na terenie Kielc w XVII i XVIII wieku. Studium z historii kultury, Kielce 2005.

Pieniążek-Samek Marta, Życie religijne w parafii kolegiackiej $w$ Kielcach $w$ XVII-XVIII wieku. Zarys problematyki, „Rocznik Muzeum Narodowego w Kielcach”, 22 (2006) s. $156-177$.

Rudnicki Kazimierz, Biskup Kajetan Sottyk 1715-1788, Warszawa 1906.

Starzyk Piotr, Dworzanie i wspótpracownicy biskupa Kajetana Ignacego Sołtyka w latach 1759-1788, „Studia Muzealno-Historyczne”, 3 (2011) s. 115-146.

Syta Krzysztof, Archiwa magnackie w XVIII wieku. Studium kultury kancelaryjno-archiwalnej, Toruń 2010.

Śladowska Maria, Polityka Augusta II wobec Kościoła katolickiego w Polsce oraz relacje z kuria rzymska w świetle korespondencji króla z kardynałem Annibalem Albanim w latach 1716-1721, „Kronika Zamkowa”, 1-2 (2009) s. 109-142.

Tomczak Andrzej, Kancelaria biskupów włocławskich w okresie księgi wpisów (XV-XVIII w.), Toruń 1964.

Turoń Bronisław, Z dziejów kancelarii biskupów wrocławskich w Nysie w latach 16011700, „Sobótka”, 19 (1964) s. 88-96.

Urzędnicy podolscy XIV-XVIII wieku. Spisy, oprac. E. Janas, W. Kłaczewski, J. Kurtyka, A. Sochacka, Kórnik 1998.

Włoch Anna Maria, Kancelaria i dokumenty biskupa krakowskiego Piotra Wysza (13921412), „Studia Źródłoznawcze”, 46 (2009) s. 29-82.

Wójcik Walenty, Organizacja i działalność Oficjalatu Okregowego w Kielcach w latach 1635-1681, „Prawo Kanoniczne. Kwartalnik prawno-historyczny”, 30 (1987) s. 121141.

Żerelik Rościsław, Kancelaria biskupów wrocławskich do 1301 roku, Wrocław 1991. 


\title{
"COMPENDIUM ARCHIVI KIELCENSIS" - A FEW REMARKS ON THE 'KIELCE' ARCHIVE AND THE OFFICE OF THE BISHOP OF KRAKOW, KAJETAN SOLTYK
}

\begin{abstract}
The history and functioning of the archives and the Krakow bishops' office are still open research topics. The researches, however, manage to methodically complement this picture with more or less detailed considerations of specific areas of the activity of church institutions, especially at the regional level. Such considerations include studies on the functioning of the Kielce archive of Bishop Kajetan Ignacy Soltyk. The 18th-century code Compendium Archivi Kielcensis, stored in the Czartoryski Library, is one of the most important sources presenting bishop's office practice and the dimension of decentralization of episcopal administration. Moreover, a detailed analysis of this material highlights the role of Kielce city as one of the main offices of the Krakow Ordinaries, as well as the position of this site in the administration system of the Krakow Church.

The most interesting part of the discussed code is the inventory of the Kielce archive of bishop Soltyk, the content of which was examined in the article. The research also attempted to identify the circumstances in which this unit of the bishop's office was established and to determine how the stored documents are connected with Kielce. An important part of the study on the archive in question is to provide an account of its history and then present it in the wider context of the history of the Diocesan Archives in Kielce, which still function today.
\end{abstract}

Keywords: Kajetan Ignacy Soltyk, archive, bishop's office, Kielce, Czartoryski Library, Krakow diocese 